\title{
Investigating Learners' Understanding on Politeness and Gender of Advertisements in Teaching Sociolinguistics
}

\author{
Vina Fathira ${ }^{1)}$, Silvia Utami ${ }^{2}$ \\ Sekolah Tinggi Ilmu Bahasa Asing (STIBA) Persada Bunda \\ 1email: vinafathira@persadabunda.ac.id \\ ²email: silvia.utami@persadabunda.ac.id
}

\begin{abstract}
This research was based on the researchers' curiosity to investigate learners' understanding politeness and gender concept of advertisements. The advertisements were watched frequently by the learners of this digital era, nowadays. Then, the politeness and gender concept sometimes can be seen in the advertisement. Politeness and gender is part of sociolinguistics subject for English literature. The aim of the research was to investigate learners' understanding in identifying politeness and gender concept existed in advertisement. The method used in this research was quantitative followed by qualitative as additional information. The population and sample of this research was the sixth semester learners of STIBA Persada Bunda. There were 10 learners as population as well as sample of this research. The data collection technique was gained by asking the learners to choose the multiple choices of politeness and gender questions by watching the video of advertisement. Then, after collecting the data, the researchers evaluated and analyzed the test of each learner. The result of this research showed that the learners' understanding in identifying politeness and gender existed in advertisements is in low level with score 51,5 "poor" category. The factors that affected the learners' understanding were the lack of learners' understanding of theoretical concept of politeness and gender, and hard for learners to differentiate gender concept of sex concept.
\end{abstract}

Key words: advertisement, politeness and gender, teaching sociolinguistics.

\section{Investigasi Kemampuan Mahasiswa dalam Mengenali Politeness dan Gender pada Iklan di Pengajaran Sosiolinguistik}

\begin{abstract}
Abstrak
Penelitian ini didasari oleh keingintahuan peneliti tentang kemampuan mahasiswa dalam mengenali dan mengidentifikasi konsep politeness dan gender yang muncul pada iklan. Iklan merupakan hal yang sering ditonton oleh para mahasiswa di era digital seperti sekarang ini. Konsep politeness dan gender kadang-kadang juga dapat terlihat dari iklan tersebut. Konsep politeness dan gender ini merupakan bagian dari pengajaran mata kuliah sosiolinguistik untuk Program Studi Sastra Inggris. Tujuan dari penelitian ini adalah untuk menginvestigasi pemahaman mahasiswa dalam mengenali konsep politeness dan gender yang muncul pada iklan. Metode penelitian ini penelitian kuantatif
\end{abstract}


diikuti oleh kualitatif sebagai tambahan. Partisipan dalam penelitian ini adalah mahasiswa semester enam pada Sekolah Tinggi Ilmu Bahasa Asing (STIBA) Persada Bunda. Ada 10 orang mahasiswa sebagai populasi dan sampel dalam penelitian ini. Pada teknik pengumpulan data, peneliti meminta mahasiswa untuk menjawab soal pilihan berganda tentang politeness dan gender dengan memperhatikan iklan yang berbentuk video. Kemudian, setelah mengumpulkan data, peneliti menilai dan menganalisis hasil tes masing-masing mahasiswa. Dari hasil penelitian tersebut menunjukkan bahwa kemampuan mahasiswa dalam mengenali konsep politeness dan gender masih dikategorikan lemah yakni dengan nilai 51,5 yang dikategorikan "rendah" (poor). Hal tersebut dapat terlihat dari kurangnya mahasiswa dalam memahami konsep politeness pada tataran teoretis, masih sulit membedakan antara konsep gender dan sex.

Kata kunci: iklan, kesopanan dan gender, pengajaran sosiolinguistik

\section{INTRODUCTION}

Nowadays, most of EFL learners are familiar with the gadget. The gadget that they use mostly consists of advertisements. This research is based on the researchers' investigation of learners' understanding on politeness and gender concept that existed in advertisements.

Politeness and gender is part of sociolinguistics subject for English literature. Sociolinguistics subject is part of linguistics matters that related to social aspect. The aim of the research is to investigate learners' understanding in identifying politeness and gender concept existed in advertisement. As Fathira (2017) said that in university level, the learners are expected to gain a mount of information to explore their thinking in learning English.

In order to know more about the learners thinking of gender and politeness concept, the researchers conducted the research about the learners' ability in gender based on Lakoff's theory. Then politeness concept based on Brown and Levinson theory.

Based on the explanation above, the researchers was interested to conduct a study entitled "Investigating learners' understanding on politeness and gender of advertisements".

Based on the background of this study, the formulation of the study is formulated as: How is the learners' ability in understanding politeness and gender existed in advertisements?

The objective of this study is to to investigate learners' understanding in identifying politeness and gender concept existed in advertisement.

The needs to conduct the study is inevstigating learners' understanding in identifying politeness and gender concept existed in advertisement in university level are:

1. as the information for the lecturer about the learners' ability in understanding gender and politeness. 
2. as the information about the learners the difficulties level in to investigate learners' understanding in identifying politeness and gender concept existed in advertisement.

3. as the information for the following researchers in conducting the research about identifying politeness and gender concept existed in advertisement.

\section{REVIEW OF LITERATURE}

In this part, the researchers wanted to explain about politeness theory, gender and advertising language that is basic theoretical framework. The researchers tried to explain advertisement as the media in analyzing gender and politeness by Brown and Levinson and also by Lakoff.

\section{Politeness}

Holmes said about politeness concept that polite includes talk to other people appropriate in relation to hearer (Holmes, 2013: 268). Beside that, the topic of politeness is also explained by several experts quoted by Hermosilla. Del Saz's in Hermosilla (2012: 4) said that the most effect of politeness was done Brown and Levinson (1987). According to the theory of Goffman's (1967) is the concept of face (image based on the public perception of the society). Face consisted of two parts. First is positive face - the willingness to be approved and admired by others. Second is negative face-the unwillingness to be approved and admired by others.
Politeness or polite can be defined as an action to minimize the effect that might happen face threatening act (fta). As Mullany (2002) stated that theory of Brown and Levinson's, the human politeness can be outlined into 4 main strategies. It can be seen in the following point.

a. Bald on-record strategy. It is a direct way of saying things. The example: "Come in", "Pass me the bucket".

b. Positive politeness strategy. This strategy showed that the speaker recognize the hearer has willingness to be approved. This strategy is part of positive face. The example: "You must be hungry after such a long journey, would you like something to eat?"

c. Negative politeness strategy. This strategy used as a way to interact with the hearer in a nonimposing way. The example: "You must forgive me, but I forgot to bring your laptop"

d. Off-record indirect strategy. It is used to remove the speaker form any potential of preventing the FTA with implicature, or with implied meaning, or ambigu. The example: "Perhaps someone should have call you first" "Wow, it's getting cold in here"

\section{Gender}

According to Mesthrie et al. (2009: 213), Gender refers to language of woman and man. It is different from "sex"in a brief explanation. The basic features of gender conmpare to "sex" can be seen as follows. The term "sex" is biological category then gender is social and cultural category. Then, 
according to Holmes (2013: 150), gender concept fokus on description of habitual utterances of masculin and feminim. In certain scale not in absolute category.

Mostly, either man or woman will talk or have conversation by using same language. Moreover, there are some differences between man language and woman languge. Based on Lakoff's theory, there are 10 (ten) features of woman language. Holmes (2013: 286) said that 10 (ten) features of it as follows.

a) Lexical hedges or fillers, the example: "you know", "sort of", "well", "you see".

b) Tag questions, the example: "she is very nice, isn't she?"

c) Rising intonations on declaratives, the example: "it's really good".

d) 'Empty' adjectives, the example: "divine", "charming", "cute".

e) Precise colour teams, the example: "magenta", "aquamarine".

f) Intensifiers such as just and so, the example: "I like him so much".

g) 'Hypercorrect' grammar, the example: consistent use of standard verbs forms.

h) 'Superpolite' forms, the example: indirect requests, euphemisms.

i) Avoidance of strong swears words, the example: "fudge", "my goodness".

j) Emphatic stress, the example: "it was a brilliant performance".

From ten features of women language, the researchers analyzed the learners' understanding of politeness and gender existed in advertisements.

\section{Advertising}

According to Stamatelou (2015: 29), advertising language is the most language that can persuade, provoke opinion of the society to certain purposes of an advertisement. Advertisng language also bulid 'relations' that facilitate the provoking opinion of the degree of belief, the basic point that support of acceptance of the product and image.

In short, advertisement builds the interpersonal relation between the adverstising maker and consumer.

In this part, the researchers took several researches about politeness, gender and some others about advertisement that support this research. The related findings can be seen as following paragraph.

1. Stamatelou (2015) discussed on his research about the use of advertisement in order to improve the understanding in language learning of EFL class. She said that the aim of the research was to show why and how the language learning in discourse level of the advertisement can give the constribution to lerning a language. However in this research, the researchers also used gender and politeness of advertisement. It was about analytical research not using advertisement as previous research did.

2. Wambui (2014) analized about realisation of language from politeness strategies and how the advertising language can be a persuasive tools on banking advertisement. She used politeness theory by Brown and 
Levinson (1987) explained how the advertisement manipulated the language to persuade the consumer of having the product from the bank. The result showed that the advertisements have a amount of variation of positive politeness strategy. However in this research, the researchers also used analytical research on advertisement of woman language existed in advertisement not the language used in advertisement to persuade as previous research did.

3. Hermosilla (2012) in this article explained about the differences of beauty product that can be seen from the language used and consumerisme related to gender. The aim was at to investigate discourse in advertisement to understand the relation among forming the language, to see politeness theory, and social aspect of gender. The conclusion of the research showed that the speaker a must pay attention to positive and negative face of hearer. Speaker has to use some of these: positive, negative, and offrecord politeness strategy in order to recognize negative and positive face of the hearer. The attention of speaker is based on the two points, like positive and negative face of hearer that gender identity also included to two points of advertisement. Language in relation to consumerisme ideas was the basic of the discourse in avertisement. However, in the same time, the language become the important point of creativity, existance, and delivery of gender identity. It is different from this research, the researchers used gender and politeness sociolinguistics subject. It is about woman language used in advertisement not discourse analysis as previous research did.

4. Ogiermann (2009) wrote a research entitled "Politeness and in-Directness Across Cultures: A Comparison of English, German, Polish and Russian Requests". She discuseed about variation existed in different culture in realisation of speech act by analyzing request of English, Polland, and Russian. The result showed that strong enough adaptation among languages in conventional use of indirectness because every culture has different rules and prohibition in producing the language. However in this research, the researchers focused on gender and politeness existed in advertisement. It is about analytical research of woman language and politeness in advertisement not politeness and in-Directness of different cultures as previous research did.

5. Kuhi and Jadidi (2012) wrote about EFL learners' ability of Iranian in understanding and producing politeness of three types of speech acts: request, refusal, and apology. The result showed that participants have good knowledge about speech acts and politeness strategies. In requesting way, they tend to use 
indirect strategies; as well as refusing, they tend to use indirect strategies better than direct; however in apologizing way, they act by using direct strategy. The research used politeness theory by Brown \& Levinson as this research did for politeness theory, however, the research used woman language for gender theory to analyze in advertisement.

\section{METHOD}

The researchers used descriptive qualitative research design to investigate the learners' ability in answering politeness and gender concept of advertisements. Gay (2011: 214) stated that the descriptive involves collecting data to test or to answer question concerning the aim of the research. In this research, the researchers scored and analyzed data by using formula and described about the understanding politeness and gender existed in advertisement descriptively.

The population as well as the sample of this research was the fifth semester learners at STIBA Persada Bunda Pekanbaru in academic year 2017/2018. The population of this research was the sample of this study since the number of the learners below 100 persons, about 10 persons. According to Arikunto (2010:112) stated, if the population less than 100 persons, the sample will be all population number.

This research was conducted at Department of Literature of STIBA Persada Bunda Pekanbaru which is located at Jl. Diponegoro No. 42 Pekanbaru-Riau.
In this research, the researchers collected data by using test about gender based on Lakoff theory and politeness based on Brown and Levinson. The test was multiple choices test consisting of 30 questions from three different advertisements. The videos of advertisements were taken from youtube.

The collected data was analyzed by using these procedures. First, the researchers counted the number of error made by learners individually. Second, the researchers classified the questions in the same type of question. In this research the question were divided into two types of questions. They were woman languge questions and the politeness questions. level. Then, the result could be seen clearly by each component in understanding politeness and gender existed in advertisements. Formula below was used to investigate the learners' ability in understanding politeness and gender existed in advertisements.

$$
\begin{aligned}
& M=X \\
& N \\
& M=\text { mean score } \\
& X=\text { correct answer } \\
& \mathrm{N}=\text { Number of all items }
\end{aligned}
$$

Supranto in Fathira (2017: 85)

After calculating the learners score, the researchers categorized the learners' ability in understanding politeness and gender existed in advertisements by using the classification below, scoring used by STIBA Persada Bunda. 
Table 2.1 Classification of the Learners' Score

\begin{tabular}{clc}
\hline No. & \multicolumn{1}{c}{ Range } & Category \\
\hline 1 & $80-100$ & Very Good \\
\hline 2 & $65-79$ & Good \\
\hline 3 & $55-64$ & Fairly Good \\
\hline 4 & $<55$ & Poor \\
\hline \multicolumn{2}{l}{ Source: STIBA Persada } & Bunda)
\end{tabular}

\section{FINDING AND DISCUSSION}

After collecting the data, it was found that the ability of fifth semester learners of STIBA Persada Bunda Pekanbaru in understanding politeness and gender existed in advertisements were 51,5 "poor" level. It can be shown in the calculation below.

Table 3.1 The Calculation of Mean Score and Level of Ability

\begin{tabular}{lcc}
\hline No. & $\begin{array}{c}\text { Score of } \\
\text { Each } \\
\text { Learner }\end{array}$ & Category \\
\hline 1 & 72 & Good \\
2 & 59 & Fairly Good \\
3 & 59 & Fairly Good \\
4 & 53 & Poor \\
5 & 47 & Poor \\
6 & 47 & Poor \\
7 & 47 & Poor \\
8 & 47 & Poor \\
9 & 43 & Poor \\
10 & 41 & Poor \\
\hline Mean Score & $\mathbf{5 1 , 5}$ & $=$ \\
level & & "Poor" \\
\hline
\end{tabular}

From the list of each score got by learners, the calculation of each score showed that the most dominant score got by the learners was in "poor" level of category. However, there only 2 learner got "fairly good" level and only 1 learner got "good" level. To see the distribution of learners' ability in understanding politeness and gender existed in advertisements, it could be seen from the Figure below.

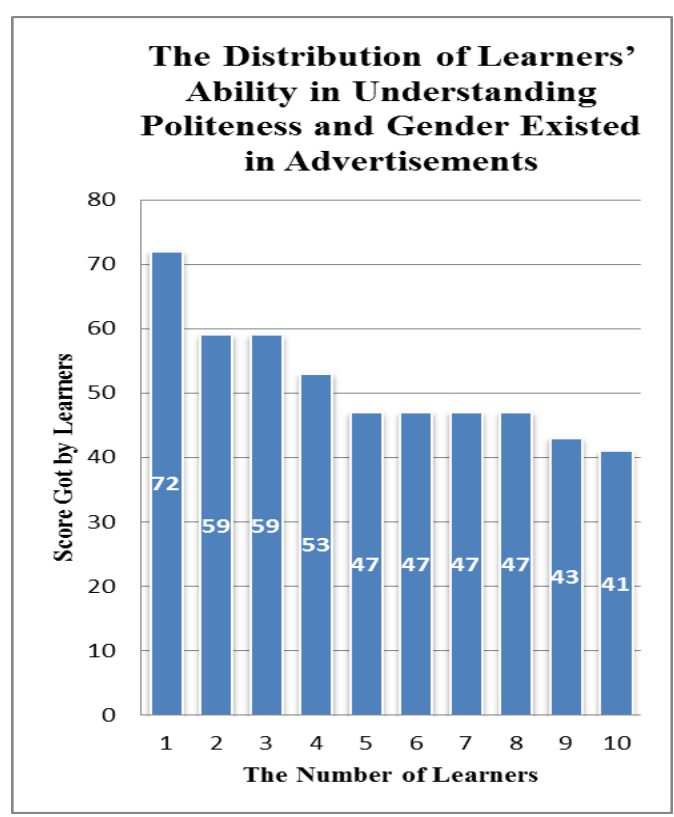

Figure 3.1

The Distribution of Learners' Ability in Understanding Politeness and Gender Existed in Advertisements

In analyzing the data, the researchers computed the number of error made by learners individually, after that, grouped the questions divided into 2 types of questionspoliteness concept and gender concept. Then the result could be seen clearly by each type of question.

The number of all questions was 30 questions from 2 advertisements. The questions consisted of woman language about 20 questions, 10 politeness theory of negative and positive face, also politeness strategy.

Based on the first advertisement, the questions number 
1 until 10 were about feature of woman language. The questions number 11until 15 were about politeness concept. Then, based on the second advertisement, the questions number 16 until 25 were about features of woman language. The questions number 26 until 30 were about politeness concept.

The distribution of the questions and the level of question could be seen in the following Table.

Table 3.2 The Distribution of the Question

\begin{tabular}{|l|l|c|}
\hline $\begin{array}{c}\text { Question } \\
\text { s }\end{array}$ & $\begin{array}{c}\text { Types of } \\
\text { Question }\end{array}$ & $\begin{array}{c}\text { Sub Topic } \\
\text { of } \\
\text { Question }\end{array}$ \\
\hline 1 to 10 & Gender & $\begin{array}{c}\text { Women } \\
\text { Language }\end{array}$ \\
\hline 11 to 15 & Politeness & Positive \\
16 to 25 & Gender & Face and \\
Negative \\
26 to 30 & Politeness & $\begin{array}{c}\text { Face, also } \\
\text { Politeness } \\
\text { Strategy }\end{array}$ \\
\hline
\end{tabular}

\subsubsection{Politeness}

In this discussion, the researchers explained about learners' ability in understanding politeness concept was categorized into "poor" level. The mean score of politeness concept that is divided into negative or positive face and politeness strategy used in those two advertisements was 40. For question for negative and positive face, the mean score got by the learners was 46. For question for politeness strategy, the mean score got by the learners was was 28 . It can be seen clearly in the following Diagram.

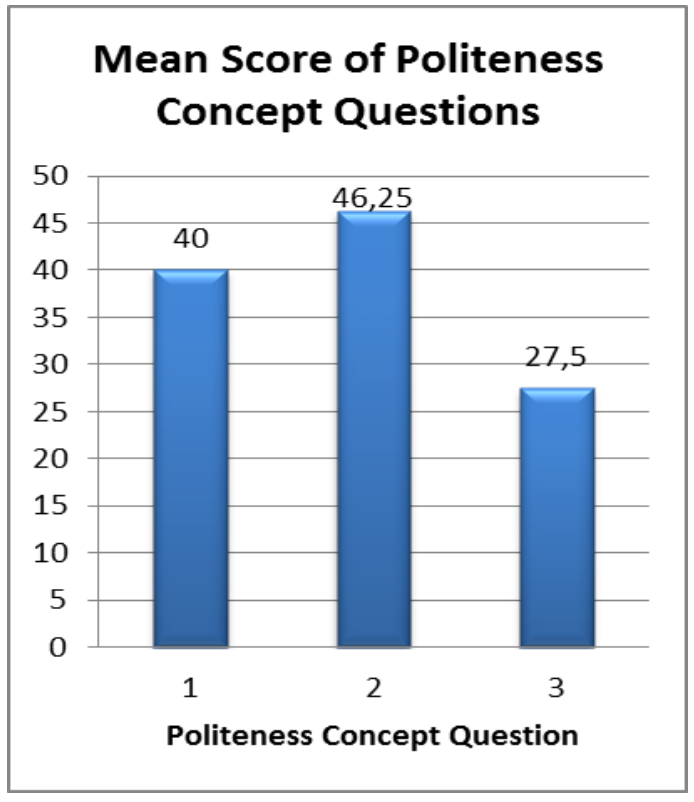

\section{Diagram 3.1 Mean Score of Politeness Concept Questions}

\subsubsection{Gender}

In this discussion, the researchers explained about learners' ability in understanding gender was categorized into "fairly good" level. The mean score of learners' ability was 58,5 . It can be seen clearly in the following Diagram.

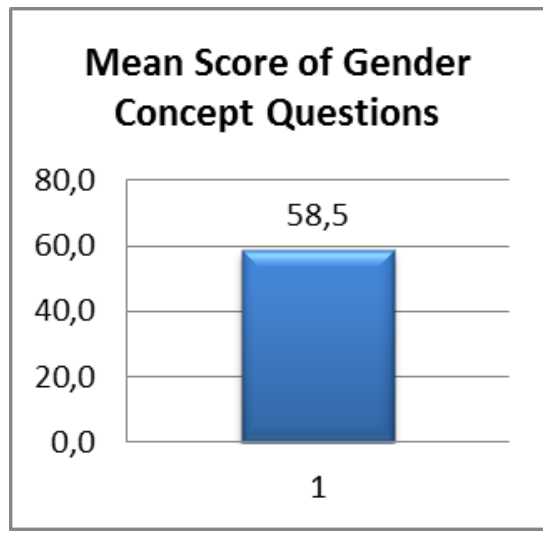

\section{Diagram 4.1 Mean Score of Gender Concept Questions}




\section{CONCLUSION}

In accordance with the objective of the research question is to answer the question "How is learners' understanding in identifying politeness and gender concept existed in advertisement?". It can be concluded that 10 fifth semester learners of STIBA Pekanbaru could not comprehend the politeness and gender concept It is categorized into "poor" level. The learners' ability in understanding politeness is "poor" for 10 questions of politeness strategy and negative or positive face. Then, the learners' ability in understanding gender concept is categorized into "fairly good" for 20 questions of woman language features.

The advertisement should pay attention to positive and negative face of hearer it was based on the gender of the speaker. This statement was in line with Hermosilia in order to pay attention to face of speaker based on gender identity.

After knowing the learners' ability in understanding politeness and gender existed in advertisements, it is important to suggest that the learners should memorize and if it is needed use an approach to improve the learners' understanding politeness and gender existed in advertisements. The learners need to be familiar with linguistic terms and theory since they learn in English Literature as well as linguistic. In this case, the learners need to have some extensive examples in daily life, in advertisements to make them remember features and politeness concept easily.

\section{REFERENCES}

Arikunto, Suharsimi. 2010. Prosedur Penelitian: Suatu Pendekatan Praktik (Edisi Revisi). Jakarta: Rineka Cipta.

Brown, Penelope and Stephen. C. Levinson. 1987. Politeness: Some Universals in Language Usage. Cambridge: C.U.P.

Fathira, Vina.2017. Analysis of EFL Students' Ability in Reading Vocabulary of Synonyms and Antonyms. Lectura: Vol 8 No.1 (2017). Retrieved from https://ejurnal.unilak.ac.id/inde x.php/lectura/article/view/426/ 309.

Gay, LR. 2011. Educational Research Competence for Anlysis and Application. Tenth Edition. New York: Pearson.

Goffman, Erving. 1967. Interaction Ritual: Essays on Face-toFace Behavior. Anchor Books.

Hermosilla, M. Sandra Vázquez. 2012. Gender and Politeness: A Case Study on Advertising Discourse. Rice Working Papers in Linguistics, Vol. 3 Spring. Retrieved from https://scholarship.rice.edu/ bitstream/handle/1911/6417 0/RWPL3_V\%C3\%A1zque $\mathrm{z} \% 20 \mathrm{Hermosilla.pdf?seque}$ nce $=1$

Holmes, Janet. 2013. An Introduction to Sociolinguistics, Fourth Edition. London: Pearson.

Kuhi and Jadidi. 2012. A Study of Iranian EFL Learners' Understanding and Production of Politeness in 
Three Speech Acts:

Request, Refusal, and Apology. Theory and Practice in Language Studies.Volume 2 No. 12, page 2624-2633. Retrieved from

http://www.academypublica tion.com/issues/past/tpls/vol 02/12/23.pdf

Mesthrie, J., et al. 2009. Introducing

Sociolinguistics. Second Edition. Edinburgh: Edinburgh University Press. Mullany, L. 2002. I don't think you want me to get a word in edgeways do you John? (Re)assessing

(im)politeness, language and gender in political broadcast interviews. Sheffield Hallam Working Papers on the Web: Linguistic Politeness and Context. Retrieved from https://extra.shu.ac.uk/wpw/ politeness/intro.htm

Ogiermann, Eva. 2009. Politeness and in-Directness Across Cultures: A Comparison of English, German, Polish and Russian Requests". Journal of Politeness Research. Page 189-216. Retrieved from https://pdfs.semanticscholar. org/bc16/fb8938d3990527e5 3d0 7889589097efa5383.p df

Saidi and Khosravi. 2015. EFL Learners' Perceptions of (im)politeness: The Possible Gender Differences. International
Journal of Language and Applied Linguistics. Page 1-11. Retrieved from http://www.khatesefid.com/ journal/wpcontent/uploads/2016/04/111.pdf

Stamatelou, Maria (2015). A Reflection on the Use of Advertisements in Enabling Language Learning in the EFL Classroom. Elted, Vol. 17 Winter. Retrieved from http://www.elted.net/upload s/7/3/1/6/7316005/v17_5sta matelou.pdf

Wambui, Ndirangu Sarah. 2014. Linguistic Politeness Strategies in Bank Advertisements: A Case Study of Kenya Commercial Bank A Research Project. Department of Linguistics and Languages University of Nairobi. Retrieved from http://erepository.uonbi.ac.k e/bitstream/handle/11295/7 7275/Ndirangu_Linguistic $\% 20$ politeness\%20strategie s\%20in\%20bank\%20adverti sements.pdf? sequence $=3$ 